\title{
New Perspectives in the Antimicrobial Activity of the Amphibian Temporin B: Peptide Analogs Are Effective Inhibitors of Candida albicans Growth
}

\author{
Anant Kakar ${ }^{1}$, Jeanett Holzknecht ${ }^{1}$, Sandrine Dubrac ${ }^{2}{ }^{\mathbb{D}}$, Maria Luisa Gelmi ${ }^{3} \mathbb{D}$, Alessandra Romanelli ${ }^{3, *}$ \\ and Florentine Marx ${ }^{1, *(D)}$ \\ 1 Biocenter, Institute of Molecular Biology, Medical University of Innsbruck, A-6020 Innsbruck, Austria; \\ anant.kakar@student.i-med.ac.at (A.K.); jeanett.holzknecht@i-med.ac.at (J.H.) \\ 2 Department of Dermatology, Venerology and Allergy, Medical University of Innsbruck, \\ A-6020 Innsbruck, Austria; sandrine.dubrac@i-med.ac.at \\ 3 Department of Pharmaceutical Sciences, University of Milan, I-20133 Milano, Italy; marialuisa.gelmi@unimi.it \\ * Correspondence: alessandra.romanelli@unimi.it (A.R.); florentine.marx@i-med.ac.at (F.M.); \\ Tel.: +39-02-5031-4475 (A.R.); +43-512-9003-70207 (F.M.)
}

check for

updates

Citation: Kakar, A.; Holzknecht, J.; Dubrac, S.; Gelmi, M.L.; Romanelli, A.; Marx, F. New Perspectives in the Antimicrobial Activity of the Amphibian Temporin B: Peptide Analogs Are Effective Inhibitors of Candida albicans Growth. J. Fungi 2021, 7, 457. https://doi.org/10.3390/ jof7060457

Academic Editor: Renátó Kovács

Received: 21 April 2021

Accepted: 31 May 2021

Published: 7 June 2021

Publisher's Note: MDPI stays neutral with regard to jurisdictional claims in published maps and institutional affiliations.

Copyright: (c) 2021 by the authors. Licensee MDPI, Basel, Switzerland. This article is an open access article distributed under the terms and conditions of the Creative Commons Attribution (CC BY) license (https:// creativecommons.org/licenses/by/ $4.0 /)$.

\begin{abstract}
Temporin B (TB) is a short, positively charged peptide secreted by the granular glands of the European frog Rana temporaria. While the antibacterial and antiviral efficacy of TB and some of its improved analogs are well documented, nothing is known about their antifungal potency so far. We dedicated this study to characterize the antifungal potential of the TB analog TB_KKG6K and the newly designed D-Lys_TB_KKG6K, the latter having the L-lysines replaced by the chiral counterpart D-lysines to improve its proteolytic stability. Both peptides inhibited the growth of opportunistic human pathogenic yeasts and killed planktonic and sessile cells of the most prevalent human pathogen, Candida albicans. The anti-yeast efficacy of the peptides coincided with the induction of intracellular reactive oxygen species. Their thermal, cation, $\mathrm{pH}$ and serum tolerance were similar, while the proteolytic stability of D-Lys_TB_KKG6K was superior to that of its template peptide. Importantly, both peptides lacked hemolytic activity and showed minimal in vitro cytotoxicity in primary human keratinocytes. The tolerance of both peptides in a reconstructed human epidermis model further supports their potential for topical application. Our results open up an exciting field of research for new anti-Candida therapeutic options based on amphibian TB analogs.
\end{abstract}

Keywords: Temporin B peptide analogs; antifungal; fungicidal activity; Candida albicans; keratinocytes; reconstructed epidermis model; skin irritation; IL-1 $\alpha$

\section{Introduction}

Temporins belong to one of the largest families of antimicrobial peptides (AMPs) and were originally isolated from the mucus secreted from granular skin glands of the European frog Rana temporaria. They represent the first line of defense of the amphibian immune system to fight microbial infections [1]. These biomolecules are mildly cationic $(0$ to +3 at $\mathrm{pH} 7)$ and short (8-14 amino acids (aa) in length), which render them highly attractive candidates for the development of novel antimicrobials, as their activity can be optimized by minor alterations of their primary structure $[2,3]$.

The membrane-active peptide Temporin B (TB; aa sequence: LLPIVGNLLKSLL; molecular weight (MW) 1392.8 Dalton (Da) was studied for its bactericidal activity against Grampositive bacteria with effective concentrations in the micromolar $(\mu \mathrm{M})$ range [4]. Efforts were made to improve the activity of this AMP against Gram-negative bacteria using an alanine scan in combination with the addition of two extra lysine residues at the N-terminus. This resulted in the peptide analog TB_KKG6A (aa sequence: KKLLPIVANLLKSLL; MW 1663.2 Da) with an elevated positive net charge (from +0.9 to $+4, \mathrm{pH} 7$ ), and a changed 
amphipathic profile and helical content, all of which significantly improved the antimicrobial activity against Gram-negative and Gram-positive bacteria and decreased the hemolytic activity $[5,6]$. Further exchanges of aa that were assumed to be involved in hydrophobic interactions with bacterial lipopolysaccharides resulted in the new analog TB_KKG6K (aa sequence: KKLLPIVKNLLKSLL; MW 1718.2 Da) that exhibited an even higher antibacterial potency than the template peptide TB_KKG6A [7].

Previous studies on the activity of TB analogs have focused primarily on their antibacterial and antiviral efficacy [6-11], while the potential of TB and its analogs against fungi was less intensively investigated. Opportunistic fungal pathogens are gaining major attention in medical, pharmaceutical and basic science, as the incidence of fungal infections is rapidly increasing. Currently, over a billion people are affected by fungal infections and more than 1.5 million deaths are caused by fungal diseases annually $[12,13]$. Fungi are eukaryotes and only a limited number of licensed antifungals are available that target cellular structures that are unique in fungi and are therefore tolerated by the host. The intensive use combined with a fungistatic mode of action provoke a highly selective pressure against some of these drugs, and the development of resistance mechanisms in fungi pose a severe impact on global health [14].

The number of infections by Candida spp. is raising dramatically, whereby Candida albicans is the most prevalent opportunistic human pathogenic yeast $[15,16]$. Residing in most individuals as a harmless commensal, $C$. albicans overgrowth can be triggered by certain conditions that compromise the health balance, e.g., alteration of the host microbiota due to medication, microbial infections or diseases and therapies that impair the immune system [17]. C. albicans can cause recurring superficial mucosal and dermal infections or invade deeper tissues and evoke systemic mycoses associated with high mortality $[18,19]$. Thus, the search for new antifungal drugs and the development of new treatment strategies with improved host tolerance has become a priority objective in the last decades.

In this study, we report for the first time on the antifungal potency of the TB peptide analog TB_KKG6K and a variant thereof, in which the L-lysines were replaced by the chiral counterpart D-lysines (D-Lys_TB_KKG6K) to improve the peptide's proteolytic tolerance. For the characterization of their antifungal potency, we applied a combination of physicochemical, microbiological and cell biological analyses, and provided a proof-ofprinciple for their tolerance on human skin cells. Our results promise a high potential for the topical application of these amphibian biomolecules in a clinical setting.

\section{Materials and Methods}

\subsection{Microorganisms, Media and Growth Conditions}

The microorganisms and culture media used in this study are listed in Tables S1 and S2, respectively. Single colonies of Candida spp. grown on potato dextrose agar (PDA) were used to inoculate $10 \mathrm{~mL}$ of $5 \%$ potato dextrose broth $(0.05 \times \mathrm{PDB})$. After overnight cultivation at $30{ }^{\circ} \mathrm{C}$ and shaking at $200 \mathrm{rpm}$, the cells were counted and diluted in $0.05 \times$ PDB to the cell number applied in the respective experiments. For the cultivation of Staphylococcus aureus, a single colony grown on tryptic soy agar (TSA) was used to inoculate $3 \mathrm{~mL}$ of tryptic soy broth (TSB) and incubated overnight at $37^{\circ} \mathrm{C}$ with shaking at $200 \mathrm{rpm}$. A 1:100 dilution in TSB was grown until the culture reached an optical density $(\mathrm{OD})$ of 0.5 at $620 \mathrm{~nm}\left(\mathrm{OD}_{620}\right)$, assuming that an $\mathrm{OD}_{620}$ of 1 correlates with $8 \times 10^{8}$ bacterial cells $\mathrm{mL}^{-1}$. The cell number was adjusted to $1 \times 10^{4} \mathrm{~mL}^{-1}$ in TSB for use in broth microdilution assays.

\subsection{Peptide Synthesis}

The TB peptides were synthesized on solid phase, using standard protocols for the Fmoc chemistry and were then purified by reversed phase-high performance liquid chromatography (RP-HPLC) and analyzed by electrospray ionization-mass spectrometry (ESI-MS; Supplementary Materials, Methods). 


\subsection{Circular Dichroism Spectroscopy}

Circular dichroism (CD) spectroscopy analysis was performed on a Jasco J-810 instrument (Hachioji, Tokyo, Japan). The peptides' concentration was measured at $205 \mathrm{~nm}$ using a molar extinction coefficient of $39,320 \mathrm{M}^{-1} \mathrm{~cm}^{-1}$. CD spectra were recorded in the $260-203 \mathrm{~nm}$ range, at $25{ }^{\circ} \mathrm{C}$ and $50 \mathrm{~nm} \mathrm{~min}{ }^{-1}$ scan speed; band width: $1 \mathrm{~nm}$; response: $2 \mathrm{~s}$; and were reported in molar ellipticity. Peptides were dissolved in $10 \mathrm{mM}$ phosphate-buffered saline (PBS, pH 7.4) or $10 \mathrm{mM}$ PBS (pH 7.4)/10 mM sodium dodecyl sulfate (SDS).

\subsection{Broth Microdilution Assays}

The inhibitory concentration of the TB peptide analogs, defined as the concentration that reduces microbial growth $\geq 90 \%$ (IC 90 ), was determined for microorganisms using broth microdilution assays carried out in 96-well microtiter plates (Nunclon Delta, Thermo Fisher Scientific, Waltham, MA, USA), as described by Holzknecht et al. [20]. One hundred $\mu \mathrm{L}$ of Candida spp. $\left(1 \times 10^{4} \mathrm{~mL}^{-1}\right.$ in $\left.0.05 \times \mathrm{PDB}\right)$ were mixed with $100 \mu \mathrm{L}$ of two-fold peptide dilutions in $0.05 \times \mathrm{PDB}$ and incubated at $30^{\circ} \mathrm{C}$ for $24 \mathrm{~h}$ under static conditions. Serial dilutions of the standard antifungal drug Amphotericin B $\left(4.0-0.015 \mu \mathrm{g} \mathrm{mL}^{-1}\right)$ were tested with $C$. albicans. The same assay conditions were applied with S. aureus, except for the test medium, where TSB was used, and the incubation temperature, which was $37^{\circ} \mathrm{C}$. To investigate the tolerance to high temperature $\left(95^{\circ} \mathrm{C}\right), \mathrm{pH} 1.5$ and $\mathrm{pH} 11$, proteolysis by trypsin, chymotrypsin and proteinase $\mathrm{K}, 1.25-5 \%(v / v)$ fetal calf serum (FCS) and the salts $\mathrm{CaCl}_{2}(0.75-3 \mathrm{mM}), \mathrm{MgCl}_{2}(1.5-6 \mathrm{mM}), \mathrm{NaCl}(50-200 \mathrm{mM})$ and $\mathrm{KCl}$ (3-12 mM), the TB peptide analogs were exposed to respective experimental conditions and the $\mathrm{IC}_{90}$ was determined against $C$. albicans (Supplementary Materials, Methods). For the evaluation of microbial growth in the broth microdilution assays, the microorganisms were resuspended by vigorous pipetting and the $\mathrm{OD}_{620}$ was measured with a multimode microplate reader (FLUOstar Omega, BMG Labtech, Ortenberg, Germany). The $\mathrm{OD}_{620}$ of the untreated control was assigned $100 \%$ growth. All samples were prepared in technical triplicates and the assays were repeated at least twice.

\subsection{Determination of the Fungicidal Activity}

C. albicans $\left(1 \times 10^{4}\right.$ cells $\left.\mathrm{mL}^{-1}\right)$ was incubated with the TB peptide analogs at concentrations corresponding to $0.25 \times$ and $1 \times \mathrm{IC}_{90}$, respectively, in $0.05 \times \mathrm{PDB}$ at $30^{\circ} \mathrm{C}$ under continuous shaking ( $800 \mathrm{rpm}$ ) in a Thermomixer Comfort (Eppendorf, Hamburg, Germany). At the time points $5 \mathrm{~min}, 6 \mathrm{~h}$ and $24 \mathrm{~h}$, aliquots were taken and plated in appropriate dilutions onto PDA plates in duplicates to stimulate the growth of viable cells. The colony-forming units (CFU) were counted after incubation at $30^{\circ} \mathrm{C}$ for $24 \mathrm{~h}$. The survival rate was calculated by comparing the number of $\mathrm{CFU}$ at the different $\mathrm{IC}_{90}$ concentrations with that of the untreated control (representing 100\% growth) at each of the defined time points. To determine the efficacy of the TB peptide analogs on sessile C. albicans cells, biofilm formation was induced by adding $100 \mu \mathrm{L}$ of C. albicans $\left(1 \times 10^{6}\right.$ cells $\left.\mathrm{mL}^{-1}\right)$ in $0.05 \times$ PDB to each well of a 96-well, flat-bottom microtiter plate (Nunclon Delta, Thermo Fisher Scientific, Waltham, MA, USA) and incubating for $24 \mathrm{~h}$ at $30^{\circ} \mathrm{C}$. The formed biofilm was then evaluated microscopically for cell attachment and pseudo-hyphae formation before proceeding with peptide application. The serially diluted TB peptide analogs (in $0.05 \times$ PDB) were added to the biofilm in $100 \mu \mathrm{L}$ aliquots to reach a final volume of $200 \mu \mathrm{L}$ per well. For the positive control, $10 \mu \mathrm{g} \mathrm{mL}^{-1}$ Amphotericin B (Sigma-Aldrich, St. Louis, MO, USA) was used, while $0.05 \times$ PDB was added to the growth control. After further incubation for $24 \mathrm{~h}$ at $30^{\circ} \mathrm{C}$, the biofilm was disrupted by vigorous pipetting, and $20 \mu \mathrm{L}$ of the detached cells were mixed with $80 \mu \mathrm{L}$ of $0.05 \times$ PDB. Appropriate dilutions were then plated in duplicates onto PDA to stimulate the growth of survivor cells. The effectiveness of the TB peptide analogs to reduce biofilm formation was calculated by comparing the number of CFU at different peptide concentrations with that of the untreated growth control. All samples were plated in duplicates and the assays were repeated at least twice. 


\subsection{Analysis of the Induction of Intracellular Reactive Oxygen Species and Cell Death}

The induction of intracellular reactive oxygen species (iROS) in C. albicans in response to the TB peptide analog exposure was detected with a fluorometric assay using the fluorogenic dye 2',7'-dichlorofluorescin diacetate (DCFH-DA; Sigma-Aldrich, St. Louis, MO, USA), as described by Sonderegger et al. [21]. The DCFH-DA stock solution (100 mM in DMSO) was added to the $C$. albicans cells $\left(1 \times 10^{7} \mathrm{~mL}^{-1}\right)$ at a final concentration of $100 \mu \mathrm{M}$. The samples were pre-incubated for $30 \mathrm{~min}$ at $30^{\circ} \mathrm{C}$ in the dark. Serial dilutions of the TB peptide analogs were prepared in $0.05 \times$ PDB in 96-well microtiter plates (Nunclon Delta, Thermo Fisher Scientific, Waltham, MA, USA) in a final volume of $100 \mu \mathrm{L}$ per well. $\mathrm{H}_{2} \mathrm{O}_{2}$ (Sigma-Aldrich, St. Louis, MO, USA) was used as a positive control for iROS induction. The DCFH-DA-loaded cells ( $100 \mu \mathrm{L}$ per well) were added to the test compounds to give a final volume of $200 \mu \mathrm{L}$ per well. To prove the peptide specific iROS induction, $50 \mu \mathrm{L}$ of ascorbic acid ( $1 \mathrm{mg} \mathrm{mL}^{-1}$ in $\mathrm{H}_{2} \mathrm{O}$; Sigma-Aldrich, St. Louis, $\left.\mathrm{MO}, \mathrm{USA}\right)$ were added to the DCFH-DA-loaded cells, resulting in an antioxidant concentration of $200 \mu \mathrm{g} \mathrm{mL} \mathrm{m}^{-1}$ in a total volume of $250 \mu \mathrm{L}$ per well. The 96 -well plate was immediately placed in a multimode microplate reader (FLUOstar Omega, BMG Labtech, Ortenberg, Germany) with a pre-set incubation temperature of $30^{\circ} \mathrm{C}$. The dichlorodihydrofluorescein (DCF) fluorescence signal was recorded every 5 min over a period of $4 \mathrm{~h}$ at excitation and emission wavelengths of 485 and $520 \mathrm{~nm}$, respectively. All samples were prepared in triplicates and the experiments were conducted at least twice. The cell death induction by TB peptide analogs was assessed with propidium iodide (PI; Sigma-Aldrich, St. Louis, MO, USA) staining, as described in the Supplementary Materials, Methods.

\subsection{Hemolytic, Cytotoxic and Skin Irritation Potential of the TB Peptide Analogs}

Assays to evaluate the induction of hemolysis and the metabolic inactivation of primary human keratinocytes by peptide exposure are described in the Supplementary Materials, Methods. The TB peptide analogs were tested for their skin irritation potential in vitro using the three-dimensional (3D) Phenion ${ }^{\circledR}$ open-source reconstructed epidermis model (Henkel, Düsseldorf, Germany) with slight adaptation from Groeber et al. and Mewes et al. [22,23] and the test guidelines 439 of the Organization for Economic Cooperation and Development (OECD) [24]. In brief, the epidermal tissue models were equilibrated in 6-well plates (STARLAB, Hamburg, Germany) with $1.5 \mathrm{~mL}$ of Phenion ${ }^{\circledR}$ OS_REp air-liquid interface (ALI) medium (Henkel, Düsseldorf, Germany) for $24 \mathrm{~h}$ at $37^{\circ} \mathrm{C}$, $5 \%(v / v) \mathrm{CO}_{2}$. Then, the medium was replaced by fresh medium and $25 \mu \mathrm{L}$ Dulbecco's phosphate-buffered saline (D-PBS) containing $50 \mu \mathrm{g}$ of the peptide, respectively, was dispensed directly on top of the models and spread gently over the surface with sterile glass applicators. The same volume of D-PBS and of $5 \%(w / v)$ aqueous SDS were applied on the negative and positive control models, respectively. All samples and controls were prepared in triplicates. After incubation at $25{ }^{\circ} \mathrm{C}$ for $35 \mathrm{~min}$, each model was thoroughly dipped six times in $1 \mathrm{~L}$ of D-PBS. The models were transferred into 6-well plates with $1.5 \mathrm{~mL}$ of Phenion ${ }^{\circledR}$ OS_REp ALI medium (Henkel, Düsseldorf, Germany) and incubated for another $24 \mathrm{~h}\left(37^{\circ} \mathrm{C}, 5 \%(v / v) \mathrm{CO}_{2}\right)$. The culture medium was collected and stored at $-80^{\circ} \mathrm{C}$ until required for cytokine quantification, which was performed according to the manufacturer's instructions (Supplementary Materials, Methods). For metabolic activity testing, the models were transferred to 24-well plates (STARLAB, Hamburg, Germany) containing $0.2 \mathrm{~mL}$ of 3-[4,5-dimethylthiazol-2-yl]-2,5-dipheyltetrazolium bromide (MTT; Sigma-Aldrich, St. Louis, MO, USA) solution ( $1 \mathrm{mg} \mathrm{mL}^{-1}$ in D-PBS) and were further incubated for $3 \mathrm{~h}\left(37^{\circ} \mathrm{C}\right.$, $\left.5 \%(v / v) \mathrm{CO}_{2}\right)$. Then, they were transferred into a new 24-well plate, and the insoluble blue formazan crystals that had formed by intracellular MTT reduction in metabolically active cells were extracted with $2 \mathrm{~mL}$ of 2-propanol [25]. After further $2 \mathrm{~h}$ of incubation at $25^{\circ} \mathrm{C}$ and shaking at $250 \mathrm{rpm}$, a sharp cannula was used to prick the insert membrane so that the tissue fluid mixed with the fluid in the wells. From each tissue sample, $200 \mu \mathrm{L}$ of the formazan extraction solution were transferred in duplicates to a 96-well microtiter plate and the optical density was measured in a multimode plate reader (FLUOstar Omega, 
BMG Labtech, Ortenberg, Germany) at a wavelength of $550 \mathrm{~nm}$. The relative metabolic activity was calculated from two replicates per tissue and three tissues per assay. The values are given as the percentage of the mean $\mathrm{OD}_{550}$ (mean $\pm \mathrm{SD}$ ) of the negative control (treated with D-PBS), which was assigned a value of $100 \%$.

\subsection{Statistics}

Data analysis was conducted with Microsoft Excel software (2016, Version 16.16.16; Microsoft Corp., Albuquerque, NM, USA). Values are given as mean \pm SD. For the calculation of significant differences between the data obtained from treated samples vs. untreated controls, a two-tailed, two-sample Student's $t$-test was applied. $p$-values of $\leq 0.05$ were considered as significant, and $p$-values of $\leq 0.005$ were considered as highly significant.

\subsection{Ethics Statement}

The study was approved by the Ethics Committee of the Medical University of Innsbruck and conducted in accordance with the Declaration of Helsinki principles. All study subjects gave written informed consent and participated voluntarily. Biopsies were taken from non-UV-exposed trunk skin of adult European healthy control subjects (AN 5073 325/4.2 360/5.8 (3804a): 2013-2017; AN 2016-0260 368/4.22 421/AM1 (4537a): 2016-2025).

\section{Results}

\subsection{Conformation of TB Peptide Analogs}

After synthesis by Fmoc chemistry and purification by RP-HPLC (Figure S1), the TB peptides were analyzed by ESI-MS, which revealed the following molecular masses in Da: TB_KKG6K 1719.23 [M+H] ${ }^{+}, 859.92[\mathrm{M}+2 \mathrm{H}]^{2+}, 573.82[\mathrm{M}+3 \mathrm{H}]^{3+}$ and D-Lys_TB_KKG6K $1719.84[\mathrm{M}+\mathrm{H}]^{+}, 860.43[\mathrm{M}+2 \mathrm{H}]^{2+}, 574.04[\mathrm{M}+3 \mathrm{H}]^{3+}$. The detected mass of the peptides corresponded to the calculated theoretical mass of $1718.18 \mathrm{Da}$, respectively. To investigate the role of the primary structure and charge distribution on the peptide's conformation and antimicrobial activity, we synthesized a peptide with a scrambled aa sequence, TB_KKG6K ${ }^{\text {scrambled }}$, in which all L-lysines were positioned at the peptide's N-terminus (aa sequence: KKKKLLPIVNLLSLL; detected MS: $1719.80[\mathrm{M}+\mathrm{H}]^{+}, 860.30[\mathrm{M}+2 \mathrm{H}]^{2+}$, $574.02 \mathrm{M}+3 \mathrm{H}]^{3+}$; calculated mass of $\left.1718.18 \mathrm{Da}\right)$. The secondary structure of the peptides was analyzed with CD spectroscopy either in $10 \mathrm{mM}$ PBS (pH 7.4), or in $10 \mathrm{mM}$ PBS/10 $\mathrm{mM}$ SDS ( $\mathrm{pH} 7.4$ ). The latter conditions were chosen to mimic the negatively charged surface of fungal membranes. Neither of the peptides adopted a defined structure in PBS, as expected (Figure S2). In the presence of SDS, however, the CD spectra of TB_KKG6K and D-Lys_TB_KKG6K showed two minima at $208 \mathrm{~nm}$ and $222 \mathrm{~nm}$, suggesting that both peptides existed in an $\alpha$-helical conformation (Figure 1). In contrast, the CD spectrum

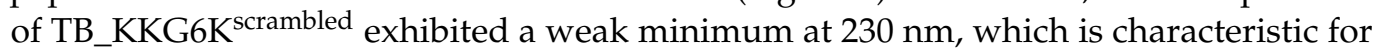
peptides that aggregate in $\beta$-sheet structures [26].

\subsection{Antimicrobial Activity of the TB Peptide Analogs}

The $\mathrm{IC}_{90}$ of the TB peptide analogs was determined against the opportunistic human pathogenic yeasts C. albicans, Candida glabrata and Candida parapsilosis in broth microdilution assays (Table 1). In addition, the Gram-positive bacterium $S$. aureus was included as a TB-sensitive control strain. TB_KKG6K and D-Lys_TB_KKG6K were similarly effective and inhibited the growth of all Candida spp., including the fluconazole-resistant clinical isolate 27700 [27] at an $\mathrm{IC}_{90}$ of $1.8 \mu \mathrm{M}$ (Table 1). For comparison, the licensed antifungal drug Amphotericin B inhibited the growth of C. albicans at the $\mathrm{IC}_{90}$ of $0.06 \mu \mathrm{M}\left(0.055 \mu \mathrm{g} \mathrm{mL}^{-1}\right)$. Interestingly, the variant TB_KKG6K ${ }^{\text {scrambled }}$ showed the same efficacy against C. albicans as the other two TB peptide analogs, which suggests that the physicochemical properties determine the antifungal activity of the peptides, while their primary structure and conformation seem to be of less importance (Table 1). All TB analogs inhibited the growth of S. aureus, but higher concentrations were necessary to limit bacterial rather than fungal growth, with TB_KKG6K being more effective (IC90 $3.6 \mu \mathrm{M})$ than $\mathrm{TB}_{-}$KKG6K ${ }^{\text {scrambled }}\left(\mathrm{IC}_{90} 7.2 \mu \mathrm{M}\right)$ and 
D-Lys_TB_KKG6K (IC $9014.4 \mu \mathrm{M})$ (Table 1). In the following study, we concentrated on the characterization of the antifungal activity of TB_KKG6K and D-Lys_TB_KKG6K.

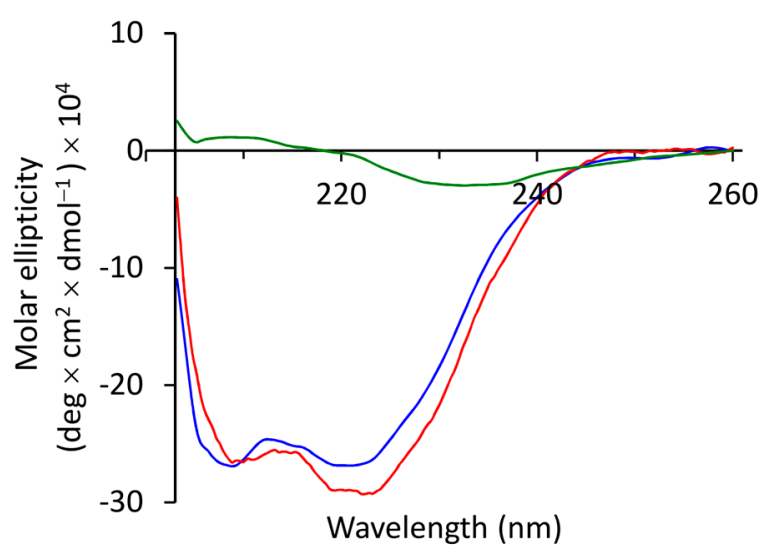

Figure 1. CD spectra of TB peptide analogs. CD spectra of TB_KKG6K (blue), D-Lys_TB_KKG6K (red) and TB_KKG6K $\mathrm{K}^{\text {scrambled }}$ (green), acquired in $10 \mathrm{mM}$ PBS/10 mM SDS (pH 7.4).

Table 1. Inhibitory concentrations $\left(\mathrm{IC}_{90}\right.$, in $\left.\mu \mathrm{M}\right)$ of the TB peptide analogs against microorganisms $\S$.

\begin{tabular}{cccc}
\hline & \multicolumn{3}{c}{ IC $_{\mathbf{9 0}}$} \\
\hline Microorganism & TB_KKG6K & D-Lys_TB_KKG6K & TB_KKG6K \\
\hline Candida albicans & 1.8 & 1.8 & 1.8 \\
\hline Candida albicans 27700 & 1.8 & 1.8 & n.d. \\
\hline Candida glabrata & 1.8 & 1.8 & n.d. \\
\hline Candida parapsilosis & 1.8 & 1.8 & n.d. \\
\hline Staphylococcus aureus & 3.6 & 14.4 & 7.2 \\
\hline
\end{tabular}

$\$$ The $\mathrm{IC}_{90}$ was defined as the peptide concentration that reduces microbial growth by $\geq 90 \%$ compared to the untreated control, which was defined as $100 \%$ growth [28]. The IC 90 was determined against yeasts and bacteria after $24 \mathrm{~h}$ of incubation in broth microdilution assays under standard conditions. n.d., not determined.

To test the TB peptide analogs for their fungicidal potential, $C$. albicans cells were incubated with the peptides at $0.25 \times$ and $1 \times \mathrm{IC}_{90}$ for $5 \mathrm{~min}, 6 \mathrm{~h}$ and $24 \mathrm{~h}$, respectively, and appropriate dilutions were plated onto PDA plates to quantify the number of cells that resumed growth after further $24 \mathrm{~h}$ of incubation by counting the CFU. The CFU of the untreated control at each time point was assigned 100\%. Figure 2 shows that both peptides significantly reduced the $\mathrm{CFU}$ counts in a concentration- and time-dependent manner. At $1 \times \mathrm{IC}_{90}$, the TB_KKG6K reduced the viability by $66 \%$ shortly after peptide addition to the Candida cells and reached $100 \%$ killing after $6 \mathrm{~h}$ of incubation. The same concentration of D-Lys_TB_KK6GK had a similar but delayed killing effect (100\% killing after $24 \mathrm{~h})$. Sublethal concentrations of the peptides $\left(0.25 \times \mathrm{IC}_{90}\right)$ resulted in a less efficient killing activity, and a slight increase in the CFU number between $6 \mathrm{~h}$ and $24 \mathrm{~h}$ of peptide exposure pointed at the resumption of fungal growth, indicating a fungistatic mode of action at this low concentration.

Next, we investigated the efficacy of the TB analogs to inhibit the growth of sessile Candida cells. To this end, a $24 \mathrm{~h}$ old biofilm was exposed to the peptides and the $\% \mathrm{CFU}$ were evaluated with a plating assay. Both TB analogs significantly reduced the number of surviving cells at a concentration $5 \times$ higher than the $\mathrm{IC}_{90}(9 \mu \mathrm{M})$ for planktonic cells and effectively killed sessile cells at a $10 \times$ higher $\mathrm{IC}_{90}$ concentration $(18 \mu \mathrm{M})$, showing a similar efficacy in biofilm reduction as $10 \mathrm{mg} \mathrm{mL}^{-1}$ Amphotericin B, which was included in the test as a positive control (Table 2). 


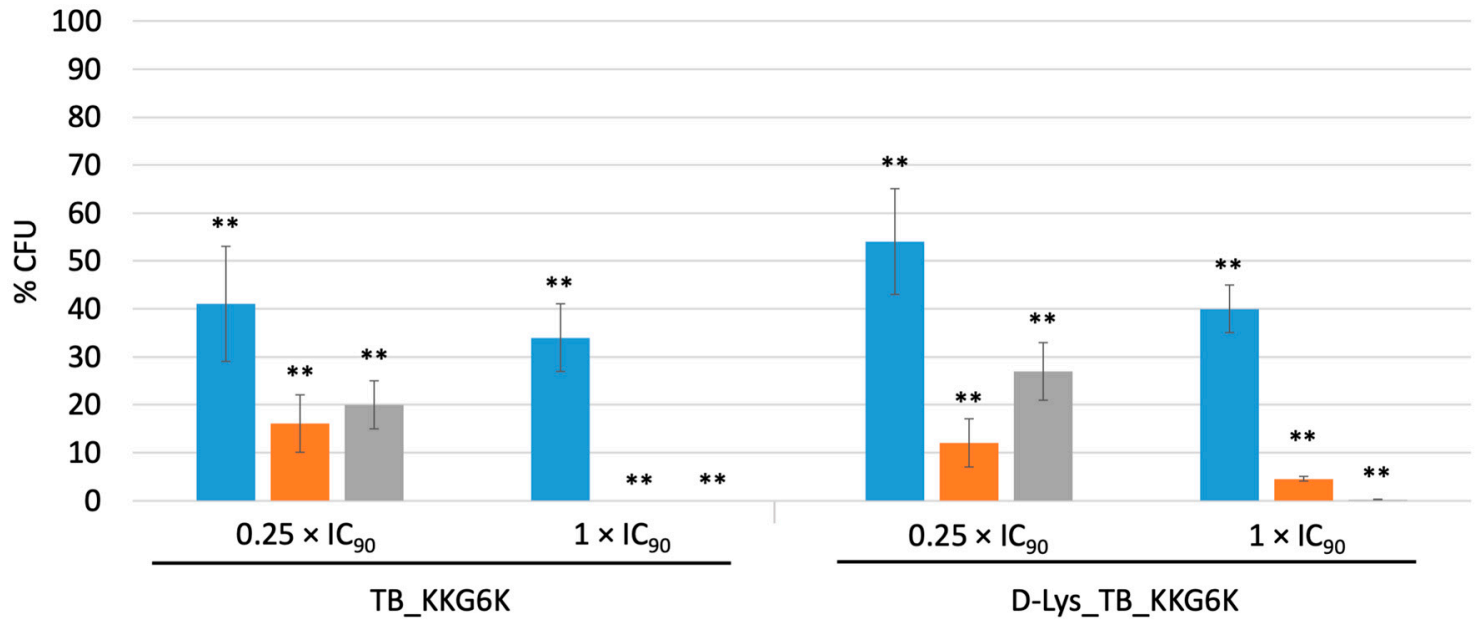

Figure 2. Candidacidal activity of the TB peptide analogs. C. albicans cells were exposed to $0.25 \times \mathrm{IC}_{90}$ and $1 \times \mathrm{IC}_{90}$ of TB_KKG6K and D-Lys TB_KKG6K, respectively, for $5 \mathrm{~min}$ (blue), $6 \mathrm{~h}$ (orange) or $24 \mathrm{~h}$ (grey). Appropriate dilutions of the samples were plated onto PDA plates and the number of CFU were determined after $24 \mathrm{~h}$ of incubation at $30{ }^{\circ} \mathrm{C}$. CFU counts without peptide treatment were assigned a value of $100 \%$ (untreated control). Values represent the mean $\pm \mathrm{SD}$ $(n=3)$. Significant differences between data of treated samples and the untreated control are indicated; ${ }^{* *} p \leq 0.005$.

Table 2. Survival of sessile C. albicans cells after exposure to the TB peptide analogs for $24 \mathrm{~h} \S$.

\begin{tabular}{ccc}
\hline Treatment & Concentration $^{\$}$ & CFU [\%] \\
\hline TB_KKG6K & $1.8(1 \times)$ & $144.0 \pm 17.3^{* *}$ \\
\hline & $9.0(5 \times)$ & $22.8 \pm 14.1^{* *}$ \\
\hline D-Lys_TB_KKG6K & $18.0(10 \times)$ & $2.8 \pm 3.3^{* *}$ \\
\hline & $1.8(1 \times)$ & $157.1 \pm 25.3^{* *}$ \\
\hline Amphotericin B & $9.0(5 \times)$ & $19.2 \pm 15.5^{* *}$ \\
\hline
\end{tabular}

$\$$ Values of surviving cells are given in \% CFU in comparison to the untreated growth control, which was set to be $100 \%$. Values represent the mean \pm SD $(n=4)$. Significant differences between the treated samples vs. the untreated growth control are indicated; ${ }^{* *} p \leq 0.005$. ${ }^{\$}$ Peptide concentrations are given in $\mu \mathrm{M}$, corresponding to the $\times$-fold IC 90 value determined for planktonic cells in broth microdilution assays (in brackets). As a control, Amphotericin B was included at a concentration of $10 \mu \mathrm{g} \mathrm{mL}^{-1}$.

\subsection{Tolerance of the TB Peptide Analogs to High Temperature, Extreme $p H$, Proteolytic Degradation, Serum and Cations}

The ability of AMPs to withstand harsh environmental conditions such as high temperature, extreme $\mathrm{pH}$, proteolytic degradation, serum compounds, and high cation concentrations are important prerequisites for their commercial feasibility as novel antimicrobial agents. The TB peptide analogs were tested for each condition and their $\mathrm{IC}_{90}$ was evaluated by applying them post-exposure in broth microdilution assays with C. albicans. As summarized in Table 3, the $1 \mathrm{~h}$ treatment at $95{ }^{\circ} \mathrm{C}$ increased the $\mathrm{IC}_{90}$ of both peptides by only one dilution step, and the exposure to $\mathrm{pH} 1.5$ and $\mathrm{pH} 11$ minimally affected the antifungal activity of D-Lys_TB_KKG6K. Expectedly, the D-lysines rendered this peptide variant more resistant against proteolysis by trypsin, chymotrypsin and proteinase $\mathrm{K}$, all of which readily inactivated TB_KKG6K (Table 3). To avoid interference of the proteases themselves on the growth of $C$. albicans, chymotrypsin and proteinase $\mathrm{K}$ were thermally inactivated $\left(95^{\circ} \mathrm{C}\right.$ for $\left.15 \mathrm{~min}\right)$ and trypsin was neutralized by the addition of $1.25 \%(\mathrm{v} / \mathrm{v})$ FCS before the protease-peptide samples were applied in the tests. The thermal treatment and the presence of FCS had no adverse effect on both peptides' activity (Tables 3 and S3). 
Table 3. Sensitivity of the TB analogs to high temperature, extreme $\mathrm{pH}$ and proteolytic degradation $\S$.

\begin{tabular}{ccc}
\hline & \multicolumn{2}{c}{ Fold Change in IC 90} \\
\hline Applied Condition & TB_KKG6K & D-Lys_TB_KKG6K \\
\hline Standard Condition & $1 \times$ & $1 \times$ \\
\hline Temperature & $2 \times$ & $2 \times$ \\
\hline $95{ }^{\circ} \mathrm{C}, 1 \mathrm{~h}$ & & $2 \times$ \\
\hline $\mathrm{pH}$ & $1 \times$ & $2 \times$ \\
\hline 1.5 & $1 \times$ & $1 \times$ \\
\hline 11 & & $2 \times$ \\
\hline Proteolytic Degradation & $>4 \times$ & $2 \times$ \\
\hline Trypsin & $>4 \times$ & \\
\hline Chymotrypsin & $>4 \times$ & \\
\hline Proteinase K & & \\
\hline
\end{tabular}

$\$$ The activity of the TB peptide analogs was evaluated by determining the fold change in their respective $\mathrm{IC}_{90} \mathrm{val}$ ues against $C$. albicans in broth microdilution assays after treatment of the peptides under the indicated conditions.

Furthermore, the activity of the TB peptide analogs against $C$. albicans was evaluated in the presence of $1.25-5 \% \mathrm{FCS}, 50-200 \mathrm{mM} \mathrm{NaCl}, 3-12 \mathrm{mM} \mathrm{KCl}, 0.75-3 \mathrm{mM} \mathrm{MgCl}_{2}$ and 1.5-6 $\mathrm{mM} \mathrm{CaCl}_{2}$ (Table 4). Both peptides retained their antifungal potential in the presence of 3-12 $\mathrm{mM} \mathrm{KCl}, 0.75 \mathrm{mM} \mathrm{MgCl} 2$ and $1.25 \%$ FCS. The peptides were most sensitive to $\mathrm{NaCl}$ and $\mathrm{CaCl}_{2}$, whereby no $\mathrm{IC}_{90}$ could be determined when the test medium was supplemented with $6 \mathrm{mM} \mathrm{CaCl}_{2}$. D-Lys_TB_KKG6K was more sensitive, showing, in general, $\mathrm{IC}_{90}$ values which were twofold higher in the presence of cations than those obtained with TB_KKG6K (Table 4).

Table 4. Fold-change in $\mathrm{IC}_{90}$ of $\mathrm{TB}$ peptide analogs in the presence of cations and heat-inactivated FCS $\$$.

\begin{tabular}{|c|c|c|}
\hline \multirow[b]{2}{*}{ Supplements } & \multicolumn{2}{|c|}{ Fold Change in $\mathrm{IC}_{90}$} \\
\hline & TB_KKG6K & D-Lys_TB_KKG6K \\
\hline \multicolumn{3}{|l|}{$\mathrm{NaCl}[\mathrm{mM}]$} \\
\hline 200 & $8 \times$ & $16 \times$ \\
\hline 100 & $4 \times$ & $16 \times$ \\
\hline 50 & $2 \times$ & $4 \times$ \\
\hline \multicolumn{3}{|l|}{$\mathrm{KCl}[\mathrm{mM}]$} \\
\hline 12 & $1 \times$ & $1 \times$ \\
\hline 6 & $1 \times$ & $1 \times$ \\
\hline 3 & $1 \times$ & $1 \times$ \\
\hline \multicolumn{3}{|l|}{$\mathrm{CaCl}_{2}[\mathrm{mM}]$} \\
\hline 6 & $>8 \times$ & $>8 \times$ \\
\hline 3 & $4 \times$ & $8 \times$ \\
\hline 1.5 & $2 \times$ & $2 \times$ \\
\hline \multicolumn{3}{|l|}{$\mathrm{MgCl}_{2}[\mathrm{mM}]$} \\
\hline 3 & $2 \times$ & $4 \times$ \\
\hline 1.5 & $1 \times$ & $2 \times$ \\
\hline 0.75 & $1 \times$ & $1 \times$ \\
\hline
\end{tabular}


Table 4. Cont.

\begin{tabular}{ccc}
\hline & \multicolumn{2}{c}{ Fold Change in IC 90} \\
\hline Supplements & TB_KKG6K & D-Lys_TB_KKG6K \\
\hline $\mathbf{M g C l}_{\mathbf{2}}[\mathrm{mM}]$ & & \\
\hline 3 & $2 \times$ & $2 \times$ \\
\hline 1.5 & $1 \times$ & $1 \times$ \\
\hline 0.75 & $1 \times$ & $4 \times$ \\
\hline FCS [\%] & & $2 \times$ \\
\hline 5 & $4 \times$ & $1 \times$ \\
\hline 2.5 & $2 \times$ & \\
\hline 1.25 & $1 \times$ & \\
\hline
\end{tabular}

$\S$ The tolerance to cations and FCS of the TB peptide analogs was evaluated by determining the fold-change in the $\mathrm{IC}_{90}$ against $C$. albicans in broth microdilution assays in the presence of the indicated supplements.

\subsection{The Induction of $i R O S$ Species by D-Lys_TB_KKG6K}

Many AMPs were reported to kill microorganisms by inducing iROS [21,29,30]. Therefore, we analyzed the iROS inducing potential of the TB peptide analogs by the use of the fluorogenic dye DCFH-DA that is converted intracellularly to the fluorescent DCF when oxidized in the presence of iROS [31]. Both peptides induced iROS at a similar level in a timeand concentration-dependent manner. Figure 3 shows the iROS burden (represented by relative fluorescence units RFU) in C. albicans exposed for $1 \mathrm{~h}$ and $4 \mathrm{~h}$ to $1 \times-8 \times \mathrm{IC}_{90}$ of the TB peptide analogs, respectively. At both time points, peptide concentrations $\geq 4 \times \mathrm{IC}_{90}$ induced higher iROS levels than $80 \mathrm{mM} \mathrm{H}_{2} \mathrm{O}_{2}$, which was used as an iROS inducing positive control. The untreated cells (negative control) showed low RFU levels at the respective time points (Figure 3).

(A)

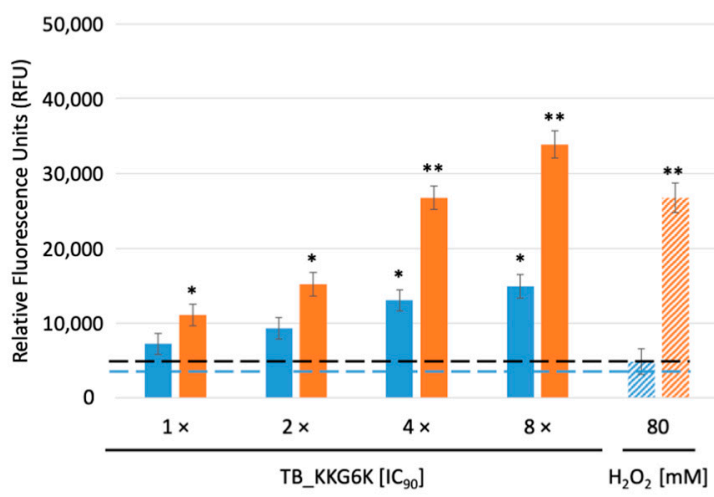

(B)

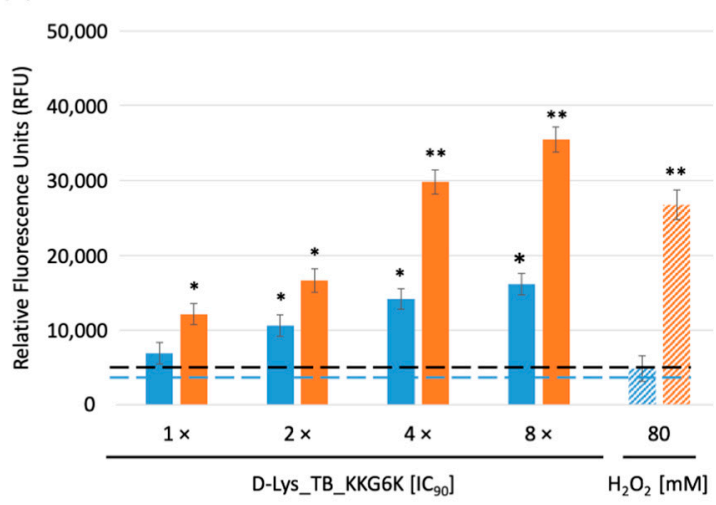

Figure 3. Induction of iROS in C. albicans after $1 \mathrm{~h}$ (blue bars) and $4 \mathrm{~h}$ (orange bars) of treatment with TB-KKG6K and D-Lys_TB_KKG6K. The fluorescent DCF signal is given in RFU. The dashed blue line represents the background RFU (3682 \pm 284$)$ at the $1 \mathrm{~h}$ time point, the dashed black line the RFU $(4798 \pm 391)$ at the $4 \mathrm{~h}$ time point of the untreated, negative control, respectively. As a positive control, $80 \mathrm{mM}$ of the iROS inducer $\mathrm{H}_{2} \mathrm{O}_{2}$ (patterned bars, extreme right in (A) and (B), respectively) was used. Values represent mean $\pm S D(n=3)$. Significant differences between data of the treated samples and the negative control are indicated; $* \leq 0.05$ and ${ }^{* *} p \leq 0.005$.

The addition of $1 \mathrm{mM}$ ascorbic acid to the test system prevented the induction of $\mathrm{iROS}$ in C. albicans, as shown for D-Lys_TB_KKG6K (Figure S3A). Concomitantly, the induction of plasma membrane permeabilization and cell death was prevented, as visualized with PI (Figure S3B). This fluorescent dye is membrane impermeable, but is internalized and binds to nucleic acids when the plasma membrane is permeabilized, which is an indicator of cell death. 


\subsection{Analysis of the Impact of D-Lys_TB_KKG6K on Mammalian Cells In Vitro}

The reported hemolytic and cytotoxic activity of many membrane-active, cationic AMPs on mammalian cells hamper their use as antimicrobial drugs [32,33]. For the TB peptide analog TB_KKG6A no hemolytic activity was detected [5]. Here we applied a basic disk diffusion assay to qualitatively assess the peptides' hemolytic potential. The improved analogs TB_KKG6K and D-Lys_TB_KKG6K did not induce the hemolysis of sheep erythrocytes in Columbia blood agar plates when applied at the very high amount of $50 \mu \mathrm{g}$ per disk (Figure S4). The sensitivity of the TB peptide analogs towards some cations hampers their applicability for systemic administration, though they could be feasible for the development of drugs for topical application. To explore their suitability, we evaluated the cytotoxic potential of the TB peptide analogs on primary human keratinocytes in vitro using the colorimetric 2,3-bis-(2-methoxy-4-nitro-5-sulfophenyl)-2Htetrazolium-5-carboxanilide (XTT) test (Supplementary Materials, Methods). Neither of the peptides affected the metabolic activity of the keratinocytes at the concentrations tested (3.6-57.6 $\mu \mathrm{M})$, though at the highest concentration the D-Lys_TB_KKG6K was better tolerated than its chiral counterpart TB_KKG6K (Figure S5). To approach test conditions that mimic the natural setting, we tested the irritation potential of the peptides on the $3 \mathrm{D}$ reconstructed epidermis model Phenion ${ }^{\circledR}$ OS-REp that was cultured in an ALI phase, as this has been reported to be a valuable model to detect skin irritation [22,23]. The cellular metabolic activity in response to a $35 \mathrm{~min}$ exposure to $50 \mu \mathrm{g}$ of peptides was validated by the reduction of MTT. The positive control model was exposed to $5 \%$ SDS $(w / v)$, while the negative control was treated with D-PBS. The negative control was assigned a metabolic activity of $100 \%$. As shown in Table 5, both peptides were very well tolerated by the OS-REp model, being far from the irritant categorization threshold of $\leq 50 \%$ metabolic activity compared to the negative control, while $5 \%$ SDS $(w / v)$ was cytotoxic $[22,23,34]$. In addition, we assessed the release of the proinflammatory cytokine IL- $1 \alpha$ into the culture medium after the peptide exposure as a supplementary endpoint to the metabolic activity results. None of the peptides significantly increased the IL- $1 \alpha$ concentration in the culture medium over that of the negative control, while the cytokine release was 10-fold higher in the SDS-treated control (Table 5).

Table 5. Cellular metabolic activity of the in vitro 3D Phenion ${ }^{\circledR}$ OS-REp model and release of proinflammatory cytokine IL- $1 \alpha$ in response to the treatment with the TB peptide analogs.

\begin{tabular}{cccc}
\hline Compound $^{\#}$ & Metabolic Activity [\%] & IL-1 $\alpha$ [pg $\mathbf{~ m L}^{-\mathbf{1}}$ ] & Categorization $^{\text {\$ }}$ \\
\hline D-PBS & $100 \pm 4.6$ & $20.6 \pm 8.3$ & non-irritant \\
\hline 5\% SDS & $1.0 \pm 0.1^{* *}$ & $199.2 \pm 47.7^{* *}$ & irritant \\
\hline TB_KKG6K & $94.2 \pm 2.9$ & $35.1 \pm 32.9$ & non-irritant \\
\hline D-Lys_TB_KKG6K & $91.4 \pm 2.9$ & $41.4 \pm 27.8$ & non-irritant \\
\hline
\end{tabular}

\# The peptides $(50 \mu \mathrm{g})$ were applied in $25 \mu \mathrm{L}$ aliquots per model. Values of metabolic activity after peptide treatment were calculated by comparison with the D-PBS treated model (negative irritation control), which was assigned $100 \%$ metabolic activity. SDS $(5 \%, w / v)$ was used as a positive irritation control (inhibition of metabolic activity). Metabolic activity and IL- $1 \alpha$ values represent the mean \pm SD $(n=3) .{ }^{\$}$ Irritant categorization threshold $\leq 50 \%$ metabolic activity compared to the negative control [24]. Significant differences in IL-1 $\alpha$ release between treated samples and negative control (D-PBS treated) is indicated; ${ }^{* *} p \leq 0.005$.

\section{Discussion}

In spite of the well-documented antibacterial and antiviral activity of $\mathrm{TB}$ and $\mathrm{TB}$ peptide analogs, [4,6-11] information on their antifungal potential is rather scarce. In this study, we evaluated in detail the antifungal properties of the TB peptide analog TB_KKG6K and its chiral counterpart D-Lys_TB_KKG6K. This modification was rationalized by a variety of studies, which indicated that D-aa peptide isoforms, apart from conferring an increased resistance to proteolytic degradation, exhibit increased antimicrobial efficacy and lower hemolytic activity than their L-aa peptide isoforms [35-39]. In contrast to these reports, we did not detect any elevated efficacy of D-Lys_TB_KKG6K over that of 
TB_KKG6K against the microorganisms tested in this study. On the contrary, the D-form TB peptide analog was less active against $S$. aureus, while both peptides inhibited the growth of Candida spp. with the same efficacy. D-aa enantiomers are known as helix-breakers. In D-Lys_TB_KKG6K two D-lysines are located at the more flexible N-terminus and at positions 6 and 10, relative to their position in the original TB peptide [4]. Although it is likely that changing the chirality of the central lysines at positions 6 and 10 alters the threedimensional structure of the peptide, no conformational changes were detected by CD. Similarly, the CD spectra of Temporin L analogs containing a single D-aa in their sequence matched those of the L-form peptides, but the biological activity was strongly influenced by these substitutions depending on their position [37]. Thus, we cannot exclude that a minor structural change in D-Lys_TB_KKG6K_-possibly detectable by nuclear magnetic resonance measurements - is responsible for the reduction in antibacterial activity of this peptide analog. The concentration of the positively charged lysines at the $\mathrm{N}$-terminus of TB_KKG6K ${ }^{\text {scrambled }}$ strongly influenced the peptide's structure and reduced the antibacterial but not the anti-yeast efficacy. We hypothesize that the strength of the interaction with C.albicans is determined by the total charge of the peptides, rather than by the structure and the distribution of the charged residues within the sequence. This is supported by the observation that TB_KKG6K ${ }^{\text {scrambled }}$ shows a similar antifungal activity as the two other TB analogs, although it exhibited a different conformation in the presence of SDS micelles. Due to the N-terminal localization of all positively charged lysines, it is reasonable to assume that the hydrophobic residues pack one onto the other in an antiparallel fashion whereas the positively charged N-terminus remains exposed in order to maximize the surface of interaction with the negatively charged micelles [26]. An interaction that requires a defined peptide conformation (e.g., ligand-target binding) seems rather unlikely. Differences in the composition, structure and function of the outer layers of fungi and bacteria (cell wall, plasma membrane) should also be considered for a possible interpretation of these data and might explain as well the lack of any cytotoxic and lytic activity in human cultured cells and sheep erythrocytes, respectively. Notably, sheep erythrocytes were reported to be more robust against lysis by AMPs than human erythrocytes [40]. The species-specific mode of action in relation to the peptide structure awaits further investigations in the future.

The ability of $C$. albicans to aggregate and proliferate in surface-associated biofilms is considered to be an important virulence factor in candidiasis. Biofilms exhibit properties that impact the host's response to infection, and dispersed cells from biofilms display enhanced pathogenicity [41]. Moreover, aggregated Candida cells are often less susceptible to antifungal agents, which limits effective anti-Candida treatment $[42,43]$. Therefore, the development of novel drugs with candidacidal activity, suppression/inhibition of resistance development and tolerance by the host remains a priority objective.

Both TB peptide analogs exhibited fungicidal activity on planktonic and sessile C. albicans cells, and the cell death was linked with membrane permeabilization and iROS induction. At present, we cannot conclude whether these detriments are primary or secondary effects of the peptides' mode of action, but their fungicidal potential is relevant to prevent or delay the development of resistance [44]. The TB peptide analogs were resistant to extremes of temperature and $\mathrm{pH}$ and were reasonably tolerant towards $\mathrm{KCl}, \mathrm{MgCl}_{2}$ and FCS. Expectedly, the D-Lys_TB_KKG6K exhibited higher proteolytic stability than TB_KKG6K. The high sensitivity towards $\mathrm{NaCl}$ and $\mathrm{CaCl}_{2}$, however, let us assume that the TB peptide analogs would be more suitable for topical rather than systemic administration, representing a promising alternative for the treatment of recurring dermal and mucosal infections [45]. Indeed, both peptides were very well tolerated even at very high concentrations when tested in vitro on primary human keratinocytes isolated from trunk skin biopsies, the D-Lys_TB_KKG6K being slightly better tolerated at very high concentrations than TB_KKG6K. Based on these promising results, we utilized the commercially available Phenion ${ }^{\circledR}$ OS-REp model that consisted of fully differentiated primary human keratinocytes as an alternative to conventionally used submersed skin cell culture or animal models [22,23]. The keratinocytes in the model were cultured under ALI conditions, which 
helps to promote the differentiation and stratification of the epidermis and facilitates the topical exposure of chemicals onto the Stratum corneum, thereby mimicking the application on human skin. An additional advantage of using 3D human epidermal models over animal models, apart from ethical considerations, is the tendency of the latter to result in false positives or negatives, presumably due to the differences between animal and human skin physiology $[22,23,46]$. Both peptides were equally well tolerated in the tested amounts. According to the OECD guidelines, a decrease of $50 \%$ in the cellular metabolic activity compared to the negative control classifies a compound as "irritant" [24], which occurred only with the 5\% SDS used as the test substance for irritation. The assessment of the release of the proinflammatory cytokine IL- $1 \alpha$ proved to be a sensitive and reliable indicator of cellular insult to validate the results of MTT assays $[34,47,48]$. Based on our results, both peptides can be categorized as "non-irritant compounds". It has to be evaluated in future studies if the peptides hold promise in their efficacy to reduce or eradicate the fungal load in full thickness infection models, which possess also a dermal component and can replicate epithelial-mesenchymal signaling in response to diverse stimuli or in appropriate in vivo models [49].

In summary: our work extended the small number of anti-fungal studies on amphibian Temporins and successfully proved the importance of rational peptide modifications to overcome limitations in the parent peptide, which paves the way for the development of new anti-Candida therapies.

Supplementary Materials: The following are available online at https://www.mdpi.com/article/ 10.3390/jof7060457/s1; Table S1: Microorganisms used in this study, Table S2: Media used in this study, Table S3: The impact of protease inactivation conditions on the activity of the TB peptide analogs against $C$. albicans, Figure S1: RP-HPLC profiles of pure TB peptide analogs, Figure S2: CD spectra of TB peptide analogs, Figure S3: Induction of iROS in C. albicans after treatment with D-Lys_TB_KKG6K monitored over a time period of $4 \mathrm{~h}$, Figure S4: Hemolytic activity of the TB peptide analogs, Figure S5: Cellular metabolic activity of keratinocytes in response to increasing concentrations of TB peptide analogs over a time period of $6 \mathrm{~h}$.

Author Contributions: Conceptualization, F.M. and A.R.; formal analysis, A.K., J.H. and A.R.; investigation, A.K., J.H. and A.R.; validation, A.K. and J.H.; resources, F.M., S.D., M.L.G. and A.R.; visualization, A.K., J.H. and A.R.; writing—original draft preparation, A.K. and F.M.; writing-review and editing, A.K., J.H., S.D., A.R. and F.M.; supervision, F.M.; project administration, F.M.; funding acquisition, F.M. All authors have read and agreed to the published version of the manuscript.

Funding: This research was funded by the Austrian Science Fund FWF (I3132-B21 and HOROS Doctoral Program, W1253 DK HOROS) to F.M.

Institutional Review Board Statement: The study was approved by the Ethics Committee of the Medical University of Innsbruck and conducted in accordance with the Declaration of Helsinki principles. All study subjects gave written informed consent and participated voluntarily. Biopsies were taken from non-UV-exposed trunk skin of adult European healthy control subjects (AN 5073 325/4.2 360/5.8 (3804a): 2013-2017; AN 2016-0260 368/4.22 421/AM1 (4537a): 2016-2025).

Informed Consent Statement: Not applicable.

Data Availability Statement: Not applicable.

Acknowledgments: "Open Access Funding by the Austrian Science Fund (FWF)". We thank Doris Bratschun-Khan for technical support.

Conflicts of Interest: The authors declare no conflict of interest. The funders had no role in the design of the study; in the collection, analyses, or interpretation of data; in the writing of the manuscript, or in the decision to publish the results. 


\section{References}

1. Romero, S.M.; Cardillo, A.B.; Martínez, C.M.C.; Camperi, S.A.; Giudicessi, S.L. Temporins: An approach of potential pharmaceutic candidates. Surg. Infect. 2020, 21, 309-322. [CrossRef]

2. Mangoni, M.L.; Shai, Y. Short native antimicrobial peptides and engineered ultrashort lipopeptides: Similarities and differences in cell specificities and modes of action. Cell. Mol. Life Sci. 2011, 68, 2267. [CrossRef]

3. Bezzerri, V.; Avitabile, C.; Dechecchi, M.C.; Lampronti, I.; Borgatti, M.; Montagner, G.; Cabrini, G.; Gambari, R.; Romanelli, A. Antibacterial and anti-inflammatory activity of a temporin B peptide analogue on an in vitro model of cystic fibrosis. J. Pept. Sci. 2014, 20, 822-830. [CrossRef] [PubMed]

4. Mahalka, A.K.; Kinnunen, P.K. Binding of amphipathic alpha-helical antimicrobial peptides to lipid membranes: Lessons from temporins B and L. Biochim. Biophys. Acta 2009, 1788, 1600-1609. [CrossRef] [PubMed]

5. Avitabile, C.; Netti, F.; Orefice, G.; Palmieri, M.; Nocerino, N.; Malgieri, G.; D’Andrea, L.D.; Capparelli, R.; Fattorusso, R.; Romanelli, A. Design, structural and functional characterization of a temporin-1b analog active against gram-negative bacteria. Biochim. Biophys. Acta 2013, 1830, 3767-3775. [CrossRef] [PubMed]

6. Grassi, L.; Maisetta, G.; Maccari, G.; Esin, S.; Batoni, G. Analogs of the frog-skin antimicrobial peptide temporin 1Tb exhibit a wider spectrum of activity and a stronger antibiofilm potential as compared to the parental peptide. Front. Chem. 2017, 5 , 24. [CrossRef]

7. Avitabile, C.; D'Andrea, L.D.; D'Aversa, E.; Milani, R.; Gambari, R.; Romanelli, A. Effect of acylation on the antimicrobial activity of temporin B analogues. ChemMedChem 2018, 13, 1549-1554. [CrossRef]

8. Avitabile, C.; D'Andrea, L.D.; Saviano, M.; Olivieri, M.; Cimmino, A.; Romanelli, A. Binding studies of antimicrobial peptides to Escherichia coli cells. Biochem. Biophys. Res. Commun. 2016, 478, 149-153. [CrossRef] [PubMed]

9. Marcocci, M.E.; Amatore, D.; Villa, S.; Casciaro, B.; Aimola, P.; Franci, G.; Grieco, P.; Galdiero, M.; Palamara, A.T.; Mangoni, M.L.; et al. The amphibian antimicrobial peptide temporin B inhibits in vitro herpes simplex virus 1 infection. Antimicrob. Agents Chemother. 2018, 62, e02367-17. [CrossRef]

10. Manzo, G.; Ferguson, P.M.; Gustilo, V.B.; Hind, C.K.; Clifford, M.; Bui, T.T.; Drake, A.F.; Atkinson, R.A.; Sutton, J.M.; Batoni, G.; et al. Minor sequence modifications in temporin B cause drastic changes in antibacterial potency and selectivity by fundamentally altering membrane activity. Sci. Rep. 2019, 9, 1385. [CrossRef]

11. Roy, M.; Lebeau, L.; Chessa, C.; Damour, A.; Ladram, A.; Oury, B.; Boutolleau, D.; Bodet, C.; Lévêque, N. Comparison of anti-viral activity of frog skin anti-microbial peptides temporin-SHa and $\left[\mathrm{k}^{3}\right]$ SHa to LL-37 and temporin-Tb against herpes simplex virus type 1. Viruses 2019, 11, 77. [CrossRef] [PubMed]

12. Brown, G.D.; Denning, D.W.; Gow, N.A.; Levitz, S.M.; Netea, M.G.; White, T.C. Hidden killers: Human fungal infections. Sci. Transl. Med. 2012, 4, 165rv13. [CrossRef]

13. Bongomin, F.; Gago, S.; Oladele, R.O.; Denning, D.W. Global and multi-national prevalence of fungal diseases-estimate precision. J. Fungi 2017, 3, 57. [CrossRef] [PubMed]

14. Fisher, M.C.; Gurr, S.J.; Cuomo, C.A.; Blehert, D.S.; Jin, H.; Stukenbrock, E.H.; Stajich, J.E.; Kahmann, R.; Boone, C.; Denning, D.W.; et al. Threats posed by the fungal kingdom to humans, wildlife, and agriculture. mBio 2020, 11, e00449-20. [CrossRef] [PubMed]

15. Koehler, P.; Stecher, M.; Cornely, O.A.; Koehler, D.; Vehreschild, M.; Bohlius, J.; Wisplinghoff, H.; Vehreschild, J.J. Morbidity and mortality of candidemia in Europe: An epidemiologic meta-analysis. Clin. Microbiol. Infect. 2019, 25, 1200-1212. [CrossRef] [PubMed]

16. Nikou, S.A.; Kichik, N.; Brown, R.; Ponde, N.O.; Ho, J.; Naglik, J.R.; Richardson, J.P. Candida albicans interactions with mucosal surfaces during health and disease. Pathogens 2019, 8, 53. [CrossRef] [PubMed]

17. Wall, G.; Montelongo-Jauregui, D.; Vidal Bonifacio, B.; Lopez-Ribot, J.L.; Uppuluri, P. Candida albicans biofilm growth and dispersal: Contributions to pathogenesis. Curr. Opin. Microbiol. 2019, 52, 1-6. [CrossRef]

18. Nobile, C.J.; Johnson, A.D. Candida albicans biofilms and human disease. Annu. Rev. Microbiol. 2015, 69, 71-92. [CrossRef]

19. Rajendran, R.; Sherry, L.; Nile, C.J.; Sherriff, A.; Johnson, E.M.; Hanson, M.F.; Williams, C.; Munro, C.A.; Jones, B.J.; Ramage, G. Biofilm formation is a risk factor for mortality in patients with Candida albicans bloodstream infection-Scotland, 2012-2013. Clin. Microbiol. Infect. 2016, 22, 87-93. [CrossRef]

20. Holzknecht, J.; Kühbacher, A.; Papp, C.; Farkas, A.; Váradi, G.; Marcos, J.F.; Manzanares, P.; Tóth, G.K.; Galgóczy, L.; Marx, F. The Penicillium chrysogenum Q176 antimicrobial protein PAFC effectively inhibits the growth of the opportunistic human pathogen Candida albicans. J. Fungi 2020, 6, 141. [CrossRef]

21. Sonderegger, C.; Váradi, G.; Galgóczy, L.; Kocsubé, S.; Posch, W.; Borics, A.; Dubrac, S.; Tóth, G.K.; Wilflingseder, D.; Marx, F. The evolutionary conserved $\gamma$-core motif influences the anti-Candida activity of the Penicillium chrysogenum antifungal protein PAF. Front. Microbiol. 2018, 9, 1655. [CrossRef]

22. Groeber, F.; Schober, L.; Schmid, F.F.; Traube, A.; Kolbus-Hernandez, S.; Daton, K.; Hoffmann, S.; Petersohn, D.; Schäfer-Korting, M.; Walles, H.; et al. Catch-up validation study of an in vitro skin irritation test method based on an open-source reconstructed epidermis (phase II). Toxicol. In Vitro 2016, 36, 254-261. [CrossRef]

23. Mewes, K.R.; Fischer, A.; Zöller, N.N.; Laubach, V.; Bernd, A.; Jacobs, A.; van Rompay, A.; Liebsch, M.; Pirow, R.; Petersohn, D. Catch-up validation study of an in vitro skin irritation test method based on an open-source reconstructed epidermis (phase I). Toxicol. In Vitro 2016, 36, 238-253. [CrossRef] 
24. OECD Guidelines for the Testing of Chemicals No. 439. In Vitro Skin Irritation: Reconstructed Human Epidermis Test Method 2020; Organization for Economic Cooperation and Development: Paris, France, 2020; Section 4.

25. Mosmann, T. Rapid colorimetric assay for cellular growth and survival: Application to proliferation and cytotoxicity assays. J. Immunol. Methods 1983, 65, 55-63. [CrossRef]

26. Diaferia, C.; Gianolio, E.; Palladino, P.; Arena, F.; Boffa, C.; Morelli, G.; Accardo, A. Peptide materials obtained by aggregation of polyphenylalanine conjugates as gadolinium-based magnetic resonance imaging contrast agents. Adv. Funct. Mater. 2015, 25, 7003-7016. [CrossRef]

27. Kovács, R.; Holzknecht, J.; Hargitai, Z.; Papp, C.; Farkas, A.; Borics, A. In vivo applicability of Neosartorya fischeri antifungal protein 2 (NFAP2) in treatment of vulvovaginal candidiasis. Antimicrob. Agents. Chemother. 2019, 63, e01777-18. [CrossRef]

28. Van Dijck, P.; Sjollema, J.; Cammue, B.P.A.; Lagrou, K.; Berman, J.; d’Enfert, C.; Andes, D.R.; Arendrup, M.C.; Brakhage, A.A.; Calderone, R.; et al. Methodologies for in vitro and in vivo evaluation of efficacy of antifungal and antibiofilm agents and surface coatings against fungal biofilms. Microb. Cell 2018, 5, 300-326. [CrossRef]

29. Tong, S.; Li, M.; Keyhani, N.O.; Liu, Y.; Yuan, M.; Lin, D.; Jin, D.; Li, X.; Pei, Y.; Fan, Y. Characterization of a fungal competition factor: Production of a conidial cell-wall associated antifungal peptide. PLoS Pathog. 2020, 16, e1008518. [CrossRef] [PubMed]

30. Ciociola, T.; Pertinhez, T.A.; De Simone, T.; Magliani, W.; Ferrari, E.; Belletti, S.; D'Adda, T.; Conti, S.; Giovati, L. In vitro and in vivo anti-Candida activity and structural analysis of killer peptide (kp)-derivatives. J. Fungi 2021, 7, 129. [CrossRef] [PubMed]

31. Chen, X.; Zhong, Z.; Xu, Z.; Chen, L.; Wang, Y. 2',7'-Dichlorodihydrofluorescein as a fluorescent probe for reactive oxygen species measurement: Forty years of application and controversy. Free Radic. Res. 2010, 44, 587-604. [CrossRef]

32. Mishra, B.; Wang, X.; Lushnikova, T.; Zhang, Y.; Golla, R.M.; Narayana, J.L.; Wang, C.; McGuire, T.R.; Wang, G. Antibacterial, antifungal, anticancer activities and structural bioinformatics analysis of six naturally occurring temporins. Peptides 2018, 106, 9-20. [CrossRef] [PubMed]

33. Shen, W.; He, P.; Xiao, C.; Chen, X. From antimicrobial peptides to antimicrobial poly ( $\alpha$-amino acids). Adv. Healthc. Mater. 2018, 7, e1800354. [CrossRef]

34. Küchler, S.; Henkes, D.; Eckl, K.M.; Ackermann, K.; Plendl, J.; Korting, H.C.; Hennies, H.C.; Schäfer-Korting, M. Hallmarks of atopic skin mimicked in vitro by means of a skin disease model based on FLG knock-down. Altern. Lab. Anim. 2011, 39, 471-480. [CrossRef] [PubMed]

35. Hamamoto, K.; Kida, Y.; Zhang, Y.; Shimizu, T.; Kuwano, K. Antimicrobial activity and stability to proteolysis of small linear cationic peptides with D-amino acid substitutions. Microbiol. Immunol. 2002, 46, 741-774. [CrossRef] [PubMed]

36. Huang, J.; Hao, D.; Chen, Y.; Xu, Y.; Tan, J.; Huang, Y.; Li, F.; Chen, Y. Inhibitory effects and mechanisms of physiological conditions on the activity of enantiomeric forms of an $\alpha$-helical antibacterial peptide against bacteria. Peptides 2011, 32, 1488-1495. [CrossRef]

37. Grieco, P.; Carotenuto, A.; Auriemma, L.; Saviello, M.R.; Campiglia, P.; Gomez-Monterrey, I.M.; Marcellini, L.; Luca, V.; Barra, D.; Novellino, E.; et al. The effect of d-amino acid substitution on the selectivity of temporin L towards target cells: Identification of a potent anti-Candida peptide. Biochim. Biophys. Acta 2013, 1828, 652-660. [CrossRef] [PubMed]

38. Li, H.; Anuwongcharoen, N.; Malik, A.A.; Prachayasittikul, V.; Wikberg, J.E.; Nantasenamat, C. Roles of d-amino acids on the bioactivity of host defense peptides. Int. J. Mol. Sci. 2016, 17, 1023. [CrossRef]

39. Manabe, T.; Kawasaki, K. D-form KLKLLLLLKLK-NH2 peptide exerts higher antimicrobial properties than its L-form counterpart via an association with bacterial cell wall components. Sci. Rep. 2017, 7, 43384. [CrossRef]

40. Rathinakumar, R.; Walkenhorst, W.F.; Wimley, W.C. Borad-spectrum antimicrobial peptides by rational combinatorial design and high-throughput screening: The importance of interfacial activity. J. Am. Chem. Soc. 2009, 131, 7609-7617. [CrossRef] [PubMed]

41. Eix, E.F.; Nett, J.E. How biofilm growth affects Candida-host interactions. Front. Microbiol. 2020, 11, 1437. [CrossRef] [PubMed]

42. Gulati, M.; Nobile, C.J. Candida albicans biofilms: Development, regulation, and molecular mechanisms. Microbes Infect. 2016, 18, 310-321. [CrossRef] [PubMed]

43. Rodríguez-Cerdeira, C.; Martínez-Herrera, E.; Carnero-Gregorio, M.; López-Barcenas, A.; Fabbrocini, G.; Fida, M.; El-Samahy, M.; González-Cespón, J.L. Pathogenesis and clinical relevance of Candida biofilms in vulvovaginal candidiasis. Front. Microbiol. 2020, 11, 544480. [CrossRef] [PubMed]

44. Robbins, N.; Caplan, T.; Cowen, L.E. Molecular evolution of antifungal drug resistance. Annu. Rev. Microbiol. 2017, 71, 753-775. [CrossRef]

45. Spampinato, C.; Leonardi, D. Candida infections, causes, targets, and resistance mechanisms: Traditional and alternative antifungal agents. Biomed Res. Int. 2013, 2013, 204237. [CrossRef] [PubMed]

46. Rodrigues Neves, C.; Gibbs, S. Progress on reconstructed human skin models for allergy research and identifying contact sensitizers. In Current Topics in Microbiology and Immunology; Springer: Berlin, Heidelberg, Germany, 2018; pp. 1-27.

47. Rasmussen, C.; Gratz, K.; Liebel, F.; Southall, M.; Garay, M.; Bhattacharyya, S.; Simon, N.; Vander Zanden, M.; Van Winkle, K.; Pirnstill, J.; et al. The StrataTest ${ }^{\circledR}$ human skin model, a consistent in vitro alternative for toxicological testing. Toxicol. In Vitro 2010, 24, 2021-2029. [CrossRef] [PubMed] 
48. Olsen, D.S.; Lee, M.; Turley, A.P. Assessment of test method variables for in vitro skin irritation testing of medical device extracts. Toxicol. In Vitro 2018, 50, 426-432. [CrossRef] [PubMed]

49. van den Bogaard, E.; Ilic, D.; Dubrac, S.; Tomic-Canic, M.; Bouwstra, J.; Celli, A.; Mauro, T. Barrier function of mammalian skin. Gordon research conference, Waterville Valley, New Hampshire. Perspective and consensus opinion: Good practices for using organotypic skin and epidermal equivalents in experimental dermatology research. J. Investig. Dermatol. 2019, 141, 203-205. [CrossRef] [PubMed] 